\title{
Bibliometric analysis of global scientific research on Coronavirus (COVID-19)
}

\author{
Hojat Dehghanbanadaki ${ }^{1}$, Farhad Seif ${ }^{2}$, Yasmin Vahidi ${ }^{3}$, Farideh Razi ${ }^{4}$, Ehsan Hashemi ${ }^{5}$, Majid Khoshmirsafa ${ }^{6}$, \\ Hossein Aazami*7,8 (D)
}

Received: 15 Apr 2020

Published: 23 May 2020

\begin{abstract}
Background: Since the outbreak of the novel coronavirus disease from Wuhan, China, in early December 2019, many scientists focused on this infection to find a way to deal with it. Due to the dramatic scientific growth in this field, we conducted a scientometric study to gain a better understanding of the scientific literature on COVID-19.

Methods: We extracted all COVID-19 documents indexed in the Scopus from December 1, 2019, to April 1, 2020, without any language limitation and determined their bibliometric characteristics, including document type, open accessibility status, citation counting, H-index, top cited documents, the most productive countries, institutions and journals, international collaboration, the most frequent terms and keywords, journal bibliographic coupling and cocitations.

Results: A total of 923 documents on COVID-19 were retrieved, of which 418 were original articles. All documents had received 2551 citations with an average citation of 2.76 per document and an h-index of 23 . China ranked first with 348 documents, followed by the United States $(n=160)$. The Lancet and BMJ Clinical Research Ed published the most documents (each with 74 documents) and 2 institutions (University of Hong Kong and Huazhong University of Science and Technology) ranked first in this regard. In addition, the present study analyzed the top 25 highly-cited documents (those that had received $70 \%$ of all citations).

Conclusion: This study highlighted the focused subjects on various aspects of COVID-19 literature such as pathogenesis, epidemiology, transmission, diagnosis, treatment, prevention, and its complications.
\end{abstract}

Keywords: Novel Coronavirus, COVID-19, SARS-CoV-2, Scientometrics, Bibliometrics

Conflicts of Interest: None declared

Funding: None

*This work has been published under CC BY-NC-SA 1.0 license.

Copyright $\odot$ Iran University of Medical Sciences

Cite this article as: Dehghanbanadaki H, Seif F, Vahidi Y, Razi F, Hashemi E, Khoshmirsafa M, Aazami H. Bibliometric analysis of global scientific research on Coronavirus (COVID-19). Med J Islam Repub Iran. 2020 (23 May);34:51. https://doi.org/10.47176/mjiri.34.51

\section{Introduction}

In early December 2019, an outbreak of viral infection associated with pneumonia was initiated in Wuhan, Hubei Province, China $(1,2)$. Severe acute respiratory syn-

Corresponding author: Hossein Aazami, aazami.h@tak.iums.ac.ir

1. Metabolic Disorders Research Center, Endocrinology and Metabolism MolecularCellular Sciences Institute, Tehran University of Medical Sciences, Tehran, Iran

2. Department of Immunology and Allergy, Academic Center for Education, Culture, and Research, Tehran, Iran

3. Department of Immunology, School of Medicine, Shiraz University of Medical Sciences, Shiraz, Iran

4. Endocrinology and Metabolism Research Center, Endocrinology and Metabolism Clinical Sciences Institute, Tehran University of Medical Sciences, Tehran, Iran

5. National Research Center for Transgenic Mouse, National Institute of Genetic Engineering and Biotechnology, Tehran, Iran

6. Department of Immunology, School of Medicine, Iran University of Medical Sciences, Tehran, Iran

7. Diabetes Research Center, Endocrinology and Metabolism Clinical Sciences Institute,

Tehran University of Medical Sciences, Tehran, Iran

8. Scientometrics Department, Farldea Company, Tehran, Iran
drome-Coronavirus 2 (SARS-CoV2) was identified as the cause of COVID-19, which was characterized by asymptomatic to severe infections in respiratory and gastrointes-

$\uparrow$ What is "already known" in this topic:

In early December 2019, the novel coronavirus (COVID-19) causing a cluster of pneumonia of unknown etiology originated from Wuhan, China, and spread rapidly throughout the world.

The WHO (World Health Organization) changed the status of COVID-19 outbreak from epidemic into pandemic on March $11,2020$.

$\rightarrow$ What this article adds:

Since the emergence of COVID-19, the number of publications on this topic has dramatically grown. About $84 \%$ of COVID-19 documents are open-access. The focus of COVID-19 literature in terms of countries, journals, institutions, terms, and keywords which all were discussed in detail sets out the research hotspots and important topics in this field. 
tinal systems, kidneys, and heart (3). Since the outbreak of COVID-19 worldwide, the number of cases has risen dramatically. Due to the rapid spread of COVID-19, the WHO has announced it as an urgent public health concern (4). Thus, the present study aimed to conduct a bibliometric analysis on COVID-19 articles worldwide from December 1, 2019 to April 1, 2020 to achieve the following goals: (a) to analyze the highly-cited articles in this field, (b) to present top countries, institutions, and journals, (c) to map the co-occurrences and keywords related to COVID-19, (d) to map co-contributions' network among countries, and (e) to map the bibliographic coupling and cocitation of journals for guiding other researchers about the direction of future COVID-19 articles.

\section{Methods}

\section{Data retrieval}

In this bibliometric study, we extracted all COVID-19 disease documents indexed in the Scopus from December 1, 2019, to April 1, 2020, without considering any language limitation. We searched the following queries in the Scopus database: (sars2) OR (sars-2) OR ("SARS 2") OR ("novel corona virus pneumonia") OR ("new human coronavirus") OR ("2019 novel coronavirus") OR ("2019 novel coronavirus infection") OR ("novel coronavirus") OR ("new coronavirus") OR ("severe acute respiratory syndrome coronavirus 2") OR ("sudden acute respiratory syndrome coronavirus 2") OR ("China coronavirus") OR ("Wuhan coronavirus") OR ("Wuhan seafood market pneumonia virus") OR (covid-19) OR ("COVID19 virus") OR ("Coronavirus disease 2019") OR TITLE-ABS ("coronavirus disease-19") OR ("Coronavirus disease 2019 virus") OR ("SARS-CoV-2") OR ("2019-nCoV") OR ("2019-nCoV disease") OR ("2019-nCoV infection"). Through this search strategy, 923 documents related to COVID19 were retrieved and different bibliometric aspects of all of these documents were investigated, which included document type, open accessibility of documents, citation counting, average citations per document, $\mathrm{H}$ index, top cited documents, document distribution around the world, the most productive countries, institutions and journals, collaboration between countries, the most frequent terms in the titles and abstracts, the most applying keywords, bibliographic coupling, and cocitations of journals.

\section{Data analysis}

Following the completion of data extraction, we exported all data into Microsoft Excel for statistical analysis and ranking various bibliometric indices, including top cited documents, top countries, institutions, and journals. We used GunnMap 2 (http://lert.co.nz/map/) to illustrate the worldwide distribution of documents and VOSviewer software (version 1.6.13) (5) to visualize the connection between terms, keywords, countries, and the rainbow density map of bibliographic coupling and journal cocitation. The bibliographic coupling of journals in the literature of COVID-19 reveals how many COVID-19 articles of 2 journals had been bibliography coupled. In other words, when 2 articles cite the same document in their bibliographies, they are bibliographically coupled; thus, the journal cocitation analysis indicates the number of COVID-19 articles cocited in 2 given journals (6).

\section{Results}

Through searching in the Scopus database, we extracted 923 documents written about COVID-19 from its emergence to April 1, 2020. Almost half $(n=418)$ of the retrieved documents were original articles and the remaining were 151 letters, 134 notes, 116 editorials, 75 reviews, 14 errata, 14 short surveys, and 1 data paper. Among all documents, $775(83.96 \%)$ were open access.

The total citations to all documents were 2551 times with average citations per document of 2.76 and h-index of 23. The total number of citations of original articles and reviews $(n=493)$ was 1895 , with an average citation of 3.84 per document and h-index of 19.

The global distribution of COVID-19 documents is depicted in Figure 1. In addition, Table 1 lists the first top 10 countries in the number of COVID-19 documents as well

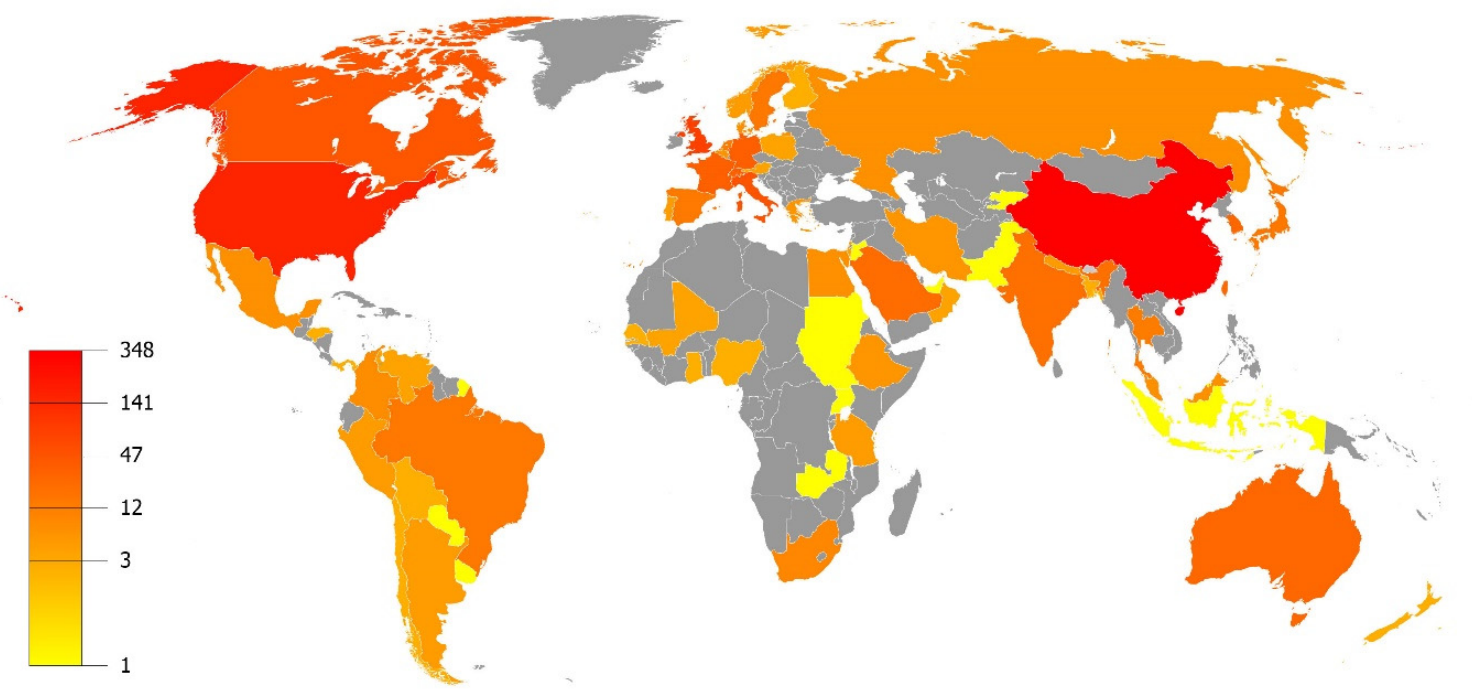

Fig. 1. The global distribution of COVID-19 scientific documents indexed in Scopus for country. The color of each country represents the number of its publications on COVID-19 


\begin{tabular}{|c|c|c|c|c|c|c|}
\hline Rank & Country & Number of publications & Rank & Country & Confirmed cases & Deaths \\
\hline 1 & China & 348 & 1 & United States & 163199 & 2850 \\
\hline 2 & United States & 160 & 2 & Italy & 105792 & 12430 \\
\hline 3 & United Kingdom & 80 & 3 & Spain & 94417 & 8189 \\
\hline 4 & Italy & 47 & 4 & China & 82638 & 3321 \\
\hline 5 & Canada & 44 & 5 & Germany & 67366 & 732 \\
\hline 6 & Hong Kong & 35 & 6 & France & 51477 & 3514 \\
\hline 7 & Germany & 34 & 7 & Iran & 47593 & 3036 \\
\hline 8 & France & 33 & 8 & United Kingdom & 25154 & 1789 \\
\hline 9 & Switzerland & 31 & 9 & Switzerland & 16108 & 373 \\
\hline 10 & Australia & 26 & 10 & Turkey & 13531 & 214 \\
\hline 10 & South Korea & 26 & & & & \\
\hline
\end{tabular}

as the number of their COVID-19 confirmed cases. China accounted for the most productive country with 348 scientific documents around the world and the number of its published documents was more than twice that of the second-ranked country, the United States, with 160 documents. The other top countries with the most documents were the United Kingdom $(n=80)$, Italy $(n=47)$, Canada $(\mathrm{n}=44)$, Hong Kong $(\mathrm{n}=35)$, Germany $(\mathrm{n}=34)$, France $(\mathrm{n}=33)$, Switzerland $(\mathrm{n}=31)$, Australia $(\mathrm{n}=26)$, and South Korea $(n=26)$. On the other hand, top 10 countries based on the number of their COVID-19 confirmed cases were the United States ( $\mathrm{n}=163199$ cases), Italy $(\mathrm{n}=105$ 792), Spain ( $\mathrm{n}=94$ 417), China $(\mathrm{n}=82$ 638), Germany ( $\mathrm{n}$ $=67$ 366), France $(n=51477)$, Iran $(n=47593)$, the United Kingdom $(n=25154)$, Switzerland $(n=16108)$, and Turkey $(\mathrm{n}=13531)$.

In addition, to illustrate the international collaboration between all 125 countries that published COVID-19 documents, we considered the countries with at least 5 documents $(\mathrm{n}=32)$. We demonstrated the international collaboration network between these 32 countries in Figure 2. The network mapping indicated a total of 241 international collaborations with the strongest collaboration between China and the United States. Furthermore, each country in this network is illustrated with different colors, representing the number of average citations per document that has been received by them. The highest average citations per document regardless of the number of publications and collaborations belonged to Denmark $(n=8)$, Belgium $(n=$ 7.2), Australia $(n=5.48)$, Hong Kong $(n=5.41)$, Netherlands $(\mathrm{n}=5.38)$, China $(\mathrm{n}=5.15)$, and Germany $(\mathrm{n}=$ 4.91). Although the United States ranked second in the number of documents, it received an average of 2.78 citations per document.

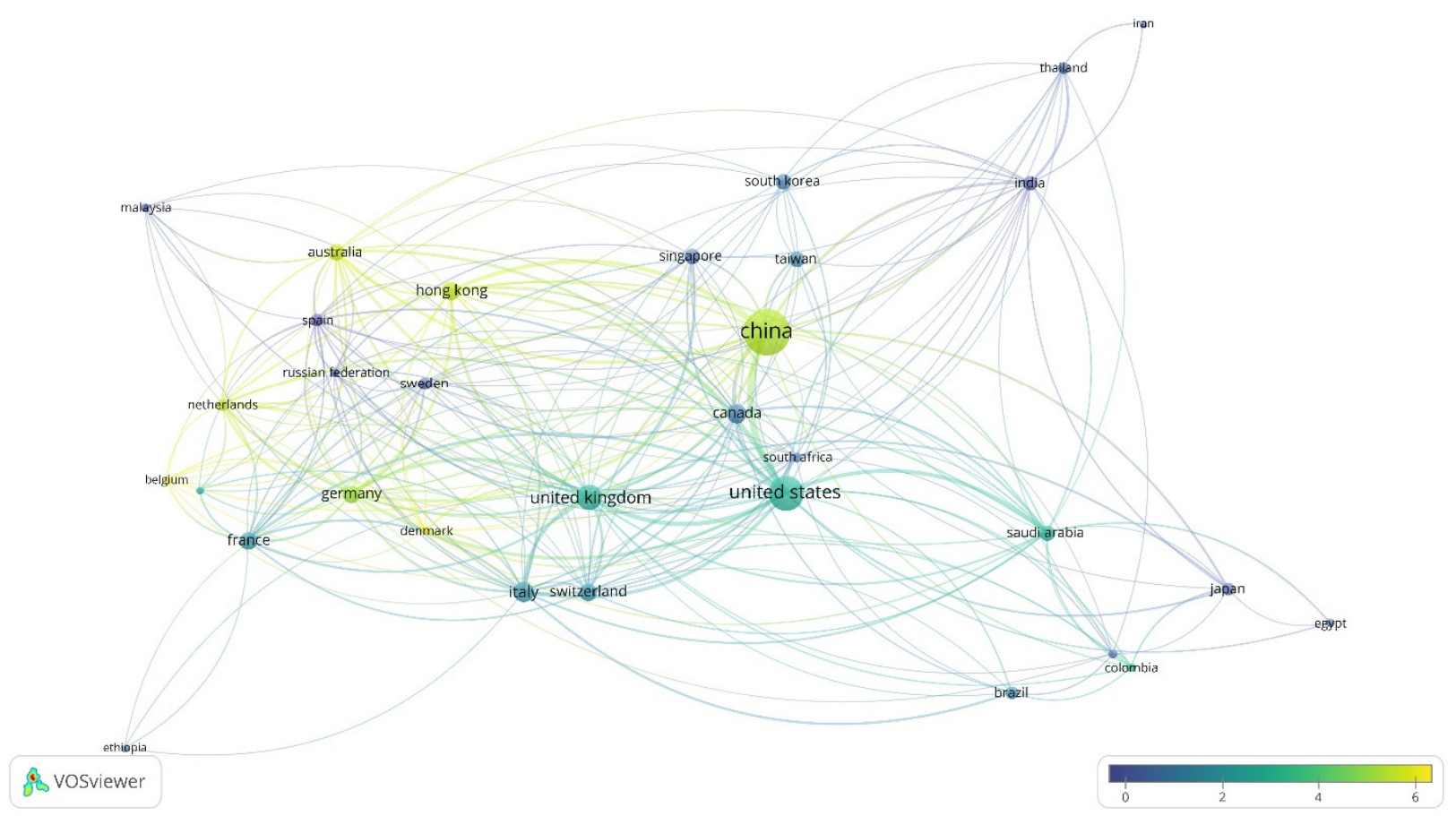

Fig. 2. The international collaboration network between the 32 countries with at least 5 COVID-19 documents is indicated. Through this network mapping, we realized there were a total of 241 collaborations with the strongest collaboration link between China and the United States. The color of each country represents the number of average citations per document that has been received by them and the size of each node represents the number of publications that has been published by that country. 
The first top 10 institutions affiliated with the retrieved documents are depicted in Table 2 that shows authors from The University of Hong Kong and Huazhong University of Science and Technology published most documents on this new emerging virus.

We also ranked the journals by which these documents have been published and we realized that most of these documents were published in highly prestigious journals (Table 3), including the Lancet ( $\mathrm{n}=74$ documents), BMJ Clinical Research Ed ( $\mathrm{n}=74$ documents), and Journal of Medical Virology ( $n=47$ documents).

The citation counting of all documents on COVID-19 discovered that many researchers were interested in 25 documents listed in Table 4.

\begin{tabular}{|c|c|c|c|c|c|c|}
\hline Rank & \multicolumn{3}{|c|}{ Affiliation } & \multicolumn{3}{|c|}{ Number of publication } \\
\hline 1 & \multicolumn{3}{|c|}{ The University of Hong Kong } & \multicolumn{3}{|c|}{30} \\
\hline 1 & \multicolumn{3}{|c|}{ Huazhong University of Science and Technology } & \multicolumn{3}{|c|}{30} \\
\hline 2 & \multicolumn{3}{|c|}{ Tongji Medical College } & \multicolumn{3}{|c|}{28} \\
\hline 3 & \multicolumn{3}{|c|}{ Chinese Academy of Sciences } & \multicolumn{3}{|c|}{25} \\
\hline 4 & \multicolumn{3}{|c|}{ Wuhan University } & \multicolumn{3}{|c|}{23} \\
\hline 5 & \multicolumn{3}{|c|}{ Capital Medical University } & \multicolumn{3}{|c|}{22} \\
\hline 5 & \multicolumn{3}{|c|}{ School of Medicine } & \multicolumn{3}{|c|}{22} \\
\hline 6 & \multicolumn{3}{|c|}{ London School of Hygiene \&amp; Tropical Medicine } & \multicolumn{3}{|c|}{20} \\
\hline 7 & \multicolumn{3}{|c|}{ Fudan University } & \multicolumn{3}{|c|}{19} \\
\hline 8 & \multicolumn{3}{|c|}{ Chinese University of Hong Kong } & \multicolumn{3}{|c|}{17} \\
\hline 8 & \multicolumn{3}{|c|}{ The University of Hong Kong Li Ka Shing Faculty of Medicine } & \multicolumn{3}{|c|}{17} \\
\hline 8 & \multicolumn{3}{|c|}{ Chinese Academy of Medical Sciences \&amp; Peking Union Medical College } & & 17 & \\
\hline 9 & & Zhejiang University School of Medi & cine & & 16 & \\
\hline 9 & & Zhongnan Hospital of Wuhan Unive & rsity & & 16 & \\
\hline 10 & & Zhejiang University & & & 15 & \\
\hline 10 & & University of Toronto & & & 15 & \\
\hline Rank & & Journal & & $\overline{\text { Nun }}$ & ber of Publicati & \\
\hline 1 & & BMJ Clinical Research Ed & & & 74 & \\
\hline 1 & & The Lancet & & & 74 & \\
\hline 2 & & Journal of Medical Virology & & & 47 & \\
\hline 3 & Euro Surve & $\begin{array}{l}\text { llance Bulletin Europeen Sur Les Maladies Transm } \\
\text { Communicable Disease Bulletin }\end{array}$ & issibles European & & 26 & \\
\hline 4 & & JAMA Journal of The American Medical Associa & tion & & 21 & \\
\hline 5 & & Lancet Infectious Diseases & & & 20 & \\
\hline 6 & & Travel Medicine And Infectious Disease & & & 15 & \\
\hline 7 & & BMJ & & & 14 & \\
\hline 7 & & Emerging Microbes And Infections & & & 14 & \\
\hline 7 & & Intensive Care Medicine & & & 14 & \\
\hline 8 & & Journal of Korean Medical Science & & & 13 & \\
\hline 8 & Zhongguo & Dang Dai Er Ke Za Zhi Chinese Journal of Contem & porary Pediatrics & & 13 & \\
\hline 9 & & Journal of Infection & & & 12 & \\
\hline 9 & & New England Journal of Medicine & & & 12 & \\
\hline 10 & & Nature & & & 11 & \\
\hline Rank & Author & Title & Source title & Citations & Article type & CiteScore \\
\hline 1 & Huang C & $\begin{array}{l}\text { Clinical features of patients infected with } 2019 \\
\text { novel coronavirus in Wuhan, China }\end{array}$ & The Lancet & 250 & Article & 10.28 \\
\hline 2 & Zhu N & $\begin{array}{l}\text { A novel coronavirus from patients with pneu- } \\
\text { monia in China, } 2019\end{array}$ & $\begin{array}{l}\text { New England Jour- } \\
\text { nal of Medicine }\end{array}$ & 180 & Article & 16.10 \\
\hline 3 & Li Q & $\begin{array}{l}\text { Early Transmission Dynamics in Wuhan, } \\
\text { China, of Novel Coronavirus-Infected Pneu- } \\
\text { monia }\end{array}$ & $\begin{array}{l}\text { The New England } \\
\text { journal of medicine }\end{array}$ & 154 & Article & 16.10 \\
\hline 4 & Chen N & $\begin{array}{l}\text { Epidemiological and clinical characteristics of } \\
99 \text { cases of } 2019 \text { novel coronavirus pneumonia } \\
\text { in Wuhan, China: a descriptive study }\end{array}$ & The Lancet & 135 & Article & 10.28 \\
\hline 4 & Chan J.F & $\begin{array}{l}\text { A familial cluster of pneumonia associated } \\
\text { with the } 2019 \text { novel coronavirus indicating } \\
\text { person-to-person transmission: a study of a } \\
\text { family cluster }\end{array}$ & The Lancet & 135 & Article & 10.28 \\
\hline 5 & Wang D & $\begin{array}{l}\text { Clinical Characteristics of } 138 \text { Hospitalized } \\
\text { Patients with } 2019 \text { Novel Coronavirus-Infected } \\
\text { Pneumonia in Wuhan, China }\end{array}$ & $\begin{array}{l}\text { JAMA - Journal of } \\
\text { the American Medi- } \\
\text { cal Association }\end{array}$ & 111 & Article & 6.98 \\
\hline 6 & Zhou P & $\begin{array}{l}\text { A pneumonia outbreak associated with a new } \\
\text { coronavirus of probable bat origin }\end{array}$ & Nature & 105 & Article & 15.21 \\
\hline
\end{tabular}




\begin{tabular}{|c|c|c|c|c|c|c|}
\hline Rank & Author & $\begin{array}{l}\text { Title } \\
\end{array}$ & Source title & Citations & Article type & CiteScore \\
\hline 7 & Lu R & $\begin{array}{l}\text { Genomic characterization and epidemiology of } \\
2019 \text { novel coronavirus: implications for virus } \\
\text { origins and receptor binding }\end{array}$ & The Lancet & 97 & Article & 10.28 \\
\hline 8 & $\begin{array}{l}\text { Holshue } \\
\text { M.L }\end{array}$ & $\begin{array}{l}\text { First case of } 2019 \text { novel coronavirus in the } \\
\text { United States }\end{array}$ & $\begin{array}{l}\text { New England Jour- } \\
\text { nal of Medicine }\end{array}$ & 66 & Article & 16.10 \\
\hline 9 & Rothe C & $\begin{array}{l}\text { Transmission of 2019-NCOV infection from } \\
\text { an asymptomatic contact in Germany }\end{array}$ & $\begin{array}{l}\text { New England Jour- } \\
\text { nal of Medicine }\end{array}$ & 62 & Letter & 16.10 \\
\hline 10 & Wang C & $\begin{array}{l}\text { A novel coronavirus outbreak of global health } \\
\text { concern }\end{array}$ & The Lancet & 55 & Note & 10.28 \\
\hline 11 & Wu J.T & $\begin{array}{l}\text { Nowcasting and forecasting the potential do- } \\
\text { mestic and international spread of the 2019- } \\
\text { nCoV outbreak originating in Wuhan, China: a } \\
\text { modeling study }\end{array}$ & The Lancet & 51 & Article & 10.28 \\
\hline 12 & Hui D.S & $\begin{array}{l}\text { The continuing } 2019-\mathrm{nCoV} \text { epidemic threat of } \\
\text { novel coronaviruses to global health - The } \\
\text { latest } 2019 \text { novel coronavirus outbreak in } \\
\text { Wuhan, China }\end{array}$ & $\begin{array}{l}\text { International Journal } \\
\text { of Infectious Dis- } \\
\text { eases }\end{array}$ & 46 & Editorial & 2.89 \\
\hline 13 & Wu F & $\begin{array}{l}\text { A new coronavirus associated with human } \\
\text { respiratory disease in China }\end{array}$ & Nature & 36 & Article & 15.21 \\
\hline 14 & Ji W & $\begin{array}{l}\text { Cross-species transmission of the newly identi- } \\
\text { fied coronavirus } 2019-\mathrm{nCoV}\end{array}$ & $\begin{array}{l}\text { Journal of Medical } \\
\text { Virology }\end{array}$ & 31 & Article & 1.94 \\
\hline 15 & Wan Y & $\begin{array}{l}\text { Receptor Recognition by the Novel Corona- } \\
\text { virus from Wuhan: an Analysis Based on } \\
\text { Decade-Long Structural Studies of SARS } \\
\text { Coronavirus }\end{array}$ & Journal of virology & 30 & Article & 4.02 \\
\hline 15 & Wu Z & $\begin{array}{l}\text { Characteristics of and Important Lessons from } \\
\text { the Coronavirus Disease } 2019 \text { (COVID-19) } \\
\text { Outbreak in China: Summary of a Report of } \\
72314 \text { Cases from the Chinese Center for } \\
\text { Disease Control and Prevention }\end{array}$ & $\begin{array}{l}\text { JAMA - Journal of } \\
\text { the American Medi- } \\
\text { cal Association }\end{array}$ & 30 & Article & 6.98 \\
\hline 16 & Chen $\mathrm{H}$ & $\begin{array}{l}\text { Clinical characteristics and intrauterine vertical } \\
\text { transmission potential of COVID-19 infection } \\
\text { in nine pregnant women: a retrospective re- } \\
\text { view of medical records }\end{array}$ & The Lancet & 29 & Article & 10.28 \\
\hline 16 & Wang $\mathrm{M}$ & $\begin{array}{l}\text { Remdesivir and chloroquine effectively inhibit } \\
\text { the recently emerged novel coronavirus (2019- } \\
\mathrm{nCoV} \text { ) in vitro }\end{array}$ & Cell Research & 29 & Letter & 8.58 \\
\hline 16 & $\begin{array}{l}\text { Corman } \\
\text { V.M }\end{array}$ & $\begin{array}{l}\text { Detection of } 2019 \text { novel coronavirus (2019- } \\
\text { nCoV) by real-time RT-PCR }\end{array}$ & $\begin{array}{c}\text { Euro surveillance : } \\
\text { bulletin Europeen } \\
\text { sur les maladies } \\
\text { transmissibles = } \\
\text { European communi- } \\
\text { cable disease bulle- } \\
\text { tin }\end{array}$ & 29 & Article & 5.05 \\
\hline 17 & Chen Y & $\begin{array}{l}\text { Emerging coronaviruses: Genome structure, } \\
\text { replication, and pathogenesis }\end{array}$ & $\begin{array}{l}\text { Journal of Medical } \\
\text { Virology }\end{array}$ & 27 & Review & 1.94 \\
\hline 18 & Munster V.J & $\begin{array}{l}\text { A novel coronavirus emerging in China - Key } \\
\text { questions for impact assessment }\end{array}$ & $\begin{array}{l}\text { New England Jour- } \\
\text { nal of Medicine }\end{array}$ & 26 & Review & 16.10 \\
\hline 18 & Chan J.F.W & $\begin{array}{l}\text { Genomic characterization of the } 2019 \text { novel } \\
\text { human-pathogenic coronavirus isolated from a } \\
\text { patient with atypical pneumonia after visiting } \\
\text { Wuhan }\end{array}$ & $\begin{array}{l}\text { Emerging Microbes } \\
\text { and Infections }\end{array}$ & 26 & Article & 4.36 \\
\hline 19 & Chung M & $\begin{array}{l}\mathrm{CT} \text { imaging features of } 2019 \text { novel corona- } \\
\text { virus }(2019-\mathrm{NCoV})\end{array}$ & Radiology & 23 & Article & 5.83 \\
\hline 20 & Xu X & $\begin{array}{l}\text { Evolution of the novel coronavirus from the } \\
\text { ongoing Wuhan outbreak and modeling of its } \\
\text { spike protein for risk of human transmission }\end{array}$ & $\begin{array}{l}\text { Science China Life } \\
\text { Sciences }\end{array}$ & 21 & Letter & 2.14 \\
\hline
\end{tabular}

In other words, these 25 documents received the most citations among all documents (1784 times which comprise almost $70 \%$ of all citations) and they ranged from 21 to 250 citations. These documents consisted of 18 original articles, 3 letters, 2 reviews, 1 editorial, and 1 note, of which 7 were published in the Lancet, 5 in the New Eng- 
land Journal of Medicine, 3 in the Euro surveillance: European communicable disease bulletin (bulletin Europeen sur les maladies transmissibles), 2 in the JAMA (Journal of the American Medical Association), 2 in Nature, 2 in the Journal of Medical Virology, and 1 in each of the International Journal of Infectious Diseases, the Journal of Virology, the Cell Research, the Emerging Microbes and Infections, the Radiology and the Science China Life Sciences.

The first document in this ranking was published by Huang C. et al (2) on January 24, 2020 and was about the clinical characteristics of COVID-19 infected patients. They reported the symptoms, signs, laboratory findings, imaging findings, underlying diseases, and complications of 41 infected patients and concluded that COVID-19 resulted in severe acute respiratory distress syndrome leading to a higher probability of ICU cases and death.

The second document in this list was a case-control study by Zhu $\mathrm{N}$ et al (7) published in the New England Journal of Medicine on February 20, 2020 and received 180 citations until the date of data extraction. This study used high-throughput sequencing technology and real time reverse transcription PCR to determine the etiology of a cluster of patients with unknown origin pneumonia linked to the Huanan seafood wholesale market in Wuhan, China. They reported that this novel infection was caused by the seventh member of the coronavirus family.

The third study by Li Q et al (8) was published in the New England Journal of Medicine on March 26, 2020, and revealed that although this novel coronavirus infected humans through zoonotic exposure, the outbreak of this infection was initiated by human to human transmission in
Wuhan since the mid-December 2019.

In this section, we investigated the terms used in the title and abstract of all COVID-19 documents and the keywords to discover the hotspot of this topic in the documents. The most frequent terms were COVID $(\mathrm{n}=983$ repeats), patient ( $\mathrm{n}=741$ repeats $), \mathrm{SARS}-\mathrm{CoV}(\mathrm{n}=593$ repeats), China ( $n=497$ repeats), case ( $n=464$ repeats), $\mathrm{nCoV}(\mathrm{n}=417$ repeats $)$, outbreak $(\mathrm{n}=355$ repeats $)$, infection ( $\mathrm{n}=344$ repeats), novel coronavirus $(\mathrm{n}=324$ repeats), Wuhan ( $\mathrm{n}=269$ repeats), Coronavirus ( $\mathrm{n}=243$ repeats), virus ( $n=204$ repeats), pneumonia $(n=195$ repeats), Coronavirus disease $(n=170$ repeats), treatment ( $n$ $=162$ repeats), transmission $(\mathrm{n}=158$ repeats $)$, study $(\mathrm{n}=$ 156 repeats), data $(n=151$ repeats), country $(n=137$ repeats), and epidemic ( $\mathrm{n}=136$ repeats).

Next, we visualized the connection network of terms applying at least 15 times in the titles and abstracts. Accordingly, 168 terms of all 8078 terms were entered into the network and clustered into 4 groups, which are demonstrated with different colors in Figure 3. The most frequent terms in each cluster are COVID (blue), SARS$\mathrm{CoV}$ (red), patient (green), and infection (yellow), respectively.

Similarly, the counting of author keywords revealed that the most co-occurrence keywords in COVID-19 documents are COVID-19 $(\mathrm{n}=139$ repeats), Coronavirus $(\mathrm{n}=$ 117 repeats), SARS-CoV-2 ( $\mathrm{n}=100$ repeats), 2019-nCOV $(\mathrm{n}=86$ repeats), pneumonia $(\mathrm{n}=34$ repeats $)$, epidemiology $(n=31$ repeats $)$, SARS $(n=24$ repeats $)$, novel Corona virus $(n=23$ repeats), Wuhan $(n=22$ repeats $)$, outbreak $(\mathrm{n}=21$ repeats), infection $(\mathrm{n}=18$ repeats), SARS-CoV ( $\mathrm{n}$ $=17$ repeats $)$, epidemic $(\mathrm{n}=13$ repeats $)$, Coronavirus dis-

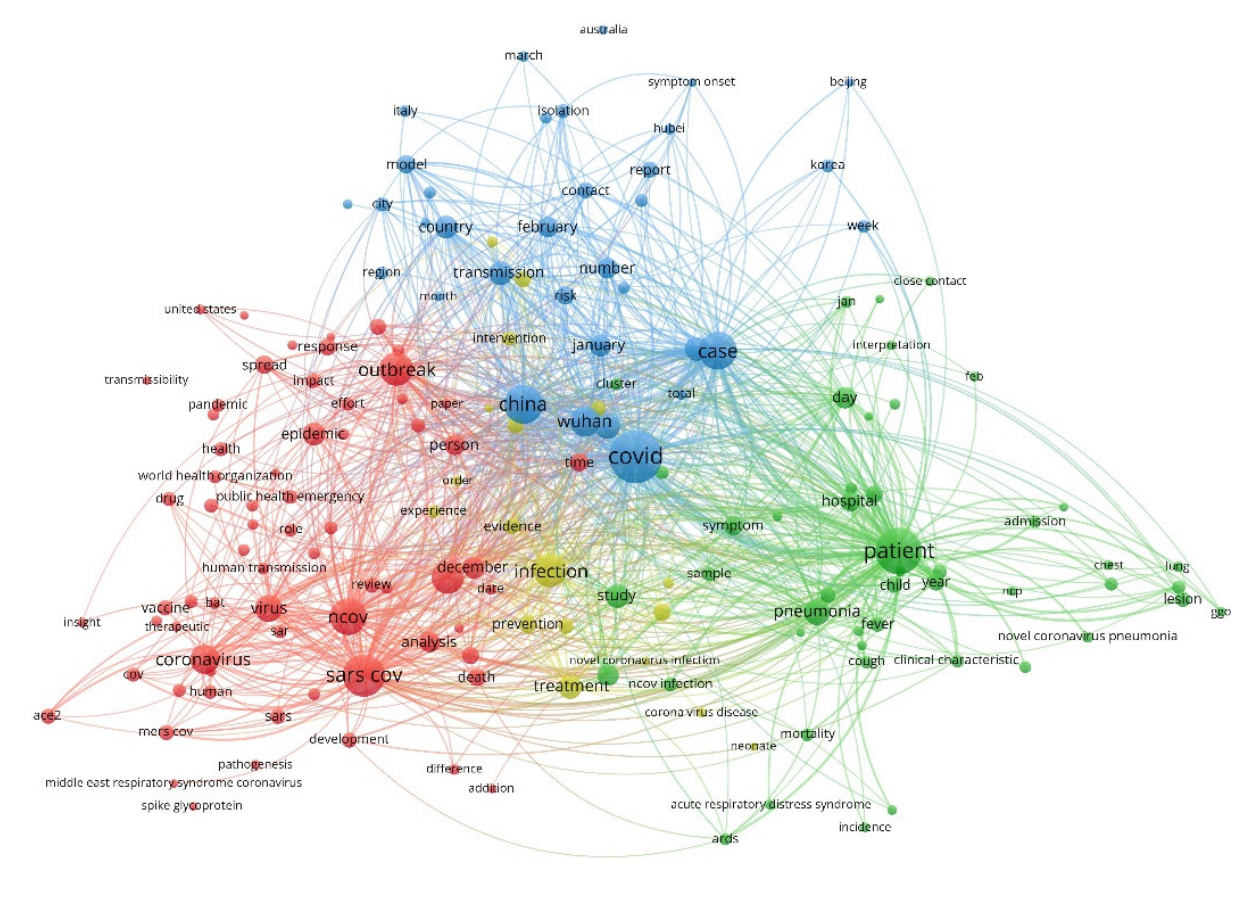

Fig. 3. The connection network of terms applying at least 15 times in the titles and abstracts. A total of 168 terms of all 8078 terms were entered into this network and clustered into 4 groups, which are shown with different colors. The most frequent terms in each cluster are COVID (blue), SARS$\mathrm{CoV}$ (red), patient (green), and infection (yellow), respectively. 
ease $2019(n=12$ repeats), China ( $n=12$ repeats), MERS $(\mathrm{n}=10$ repeats), virology $(\mathrm{n}=9$ repeats), 2019 novel Coronavirus ( $\mathrm{n}=9$ repeats), acute respiratory disease $(\mathrm{n}=$ 8 repeats), MERS-CoV ( $\mathrm{n}=8$ repeats), transmission $(\mathrm{n}=$ 8 repeats), and diagnosis ( $\mathrm{n}=8$ repeats).

To visualize the connection network between author keywords, we considered only keywords with at least 5 co-occurrences and found out that 38 of 786 keywords were entered into the network and clustered into 6 groups (Fig. 4). The most frequent keywords in each cluster are 2019-nCOV (red), Coronavirus (green), COVID-19 (dark blue), epidemiology (yellow), novel Corona virus (purple), and SARS-CoV-2 (light blue), respectively.

The bibliographic coupling of journals in the literature of COVID-19 reveals how many COVID-19 articles of 2 journals had been bibliography coupled. In other words, when 2 articles cite the same document in their bibliographies, they are bibliographically coupled. Figure 5 shows the bibliographic coupling map of journals with at least 5 COVID-19 documents. Out of 308 journals, 41 met this threshold and 32 constructed the largest coupling network (Fig. 5).

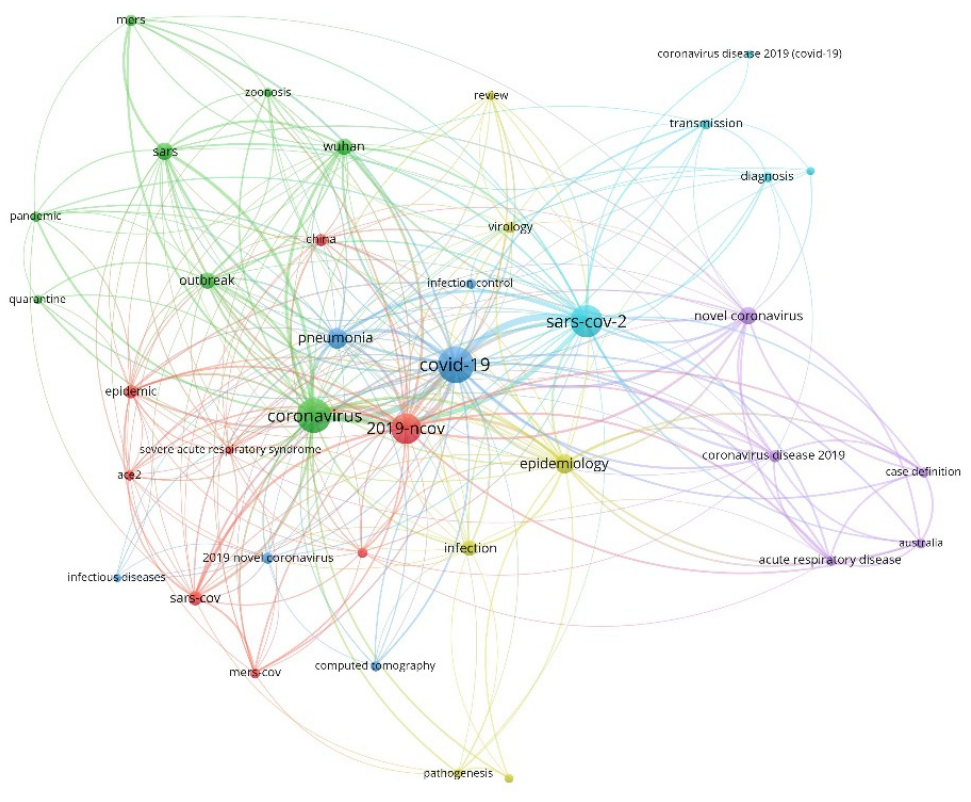

fon vosviewer

Fig. 4. The connection network between author keywords with at least 5 co-occurrences. Out of 786 keywords, 38 were entered into this network and clustered into 6 groups, which are depicted in different colors. The most frequent keywords in each cluster are 2019-nCOV (red), coronavirus (green), COVID-19 (dark blue), epidemiology (yellow), novel coronavirus (purple), and SARS-CoV-2 (light blue), respectively.

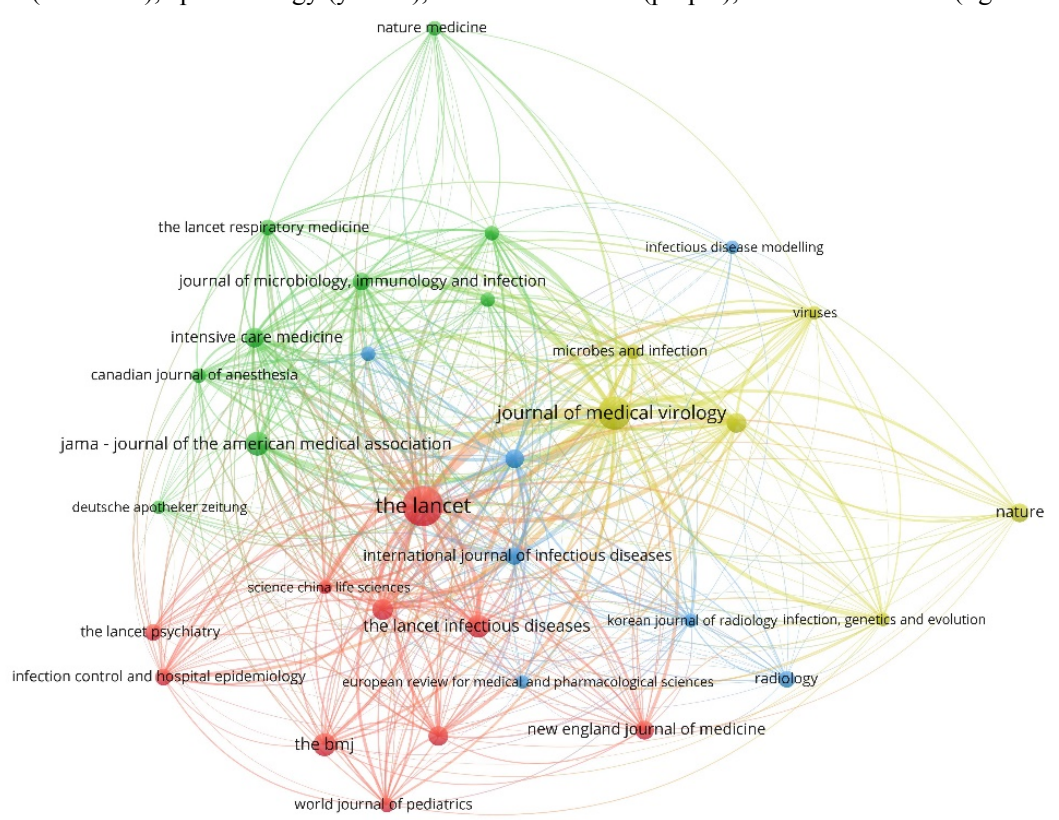

\section{\& VOSviewer}

Figure 5. The bibliographic coupling connection network of journals with at least 5 documents related to COVID-19. The bibliographic coupling of journals in the literature of 2019-nCOV reveals how many COVID-19 articles of 2 journals had been bibliography coupled. In other words, when 2 articles cite the same document in their bibliographies, they are bibliographically coupled. 


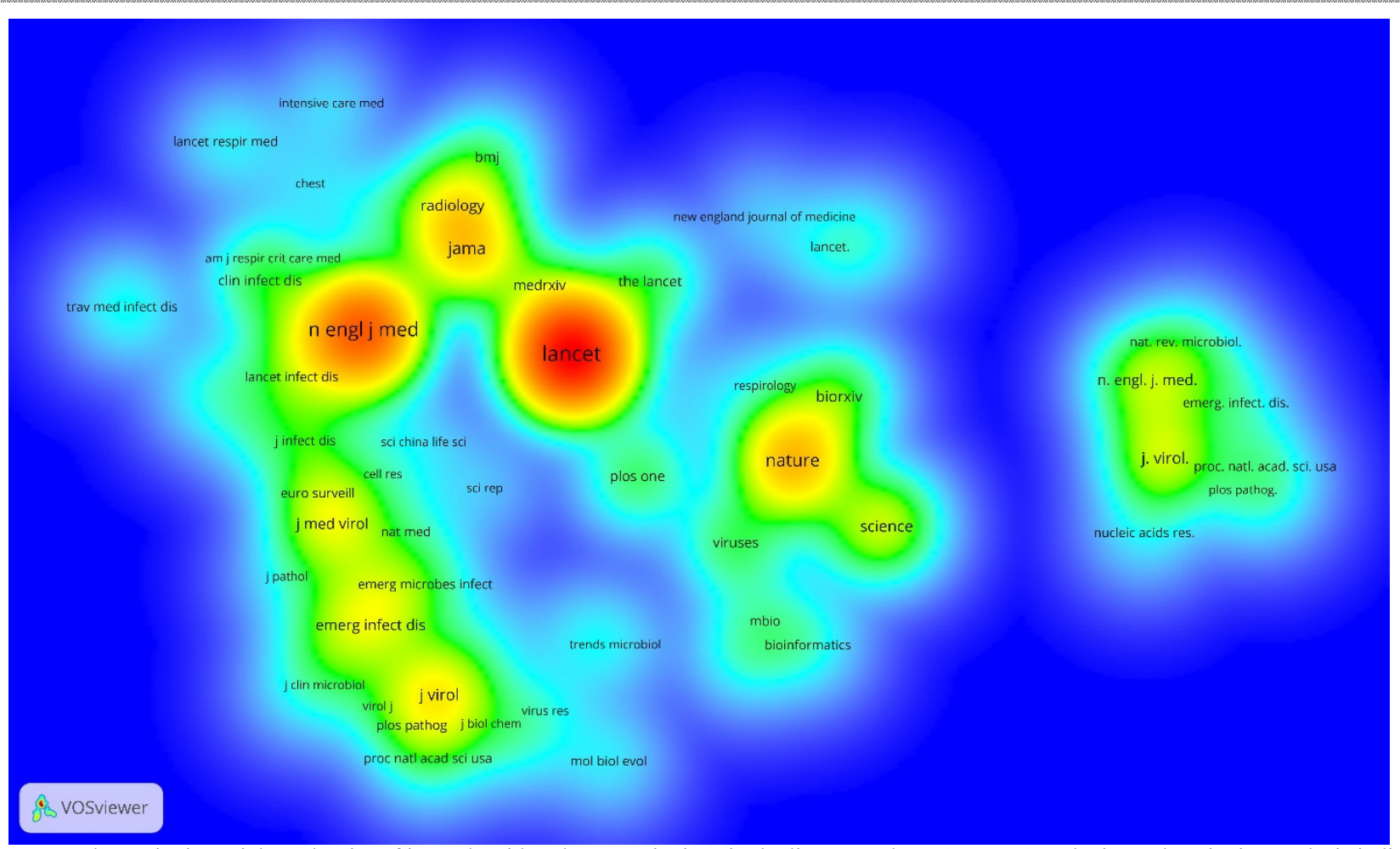

Fig. 6. The cocitation rainbow density of journals with at least 20 citations in the literature about COVID-19. The journal cocitation analysis indicates the number of 2019-nCOV articles that were cocited in 2 given journals.

In addition, the results of journal cocitation analysis indicates the number of articles that cocited the COVID-19 articles of 2 given journals. In this regard, we visualized the cocitation rainbow density of journals with at least 20 citations in the literature of COVID-19 (Fig. 6).

\section{Discussion}

In this study, we aimed to provide the perspective of COVID-19 documents in the world and identify our current position in the publication on this novel Coronavirus. We illustrated the hotspots of research on this topic so far and determined the origin of these documents from which countries, institutions, journals, and authors have arisen. This novel virus from the seventh membrane of the coronavirus family originated from Wuhan, Hubei Province, China, in early December 2019, causing a cluster of pneumonia with an unknown etiology that almost all patients linked to the Huanan seafood wholesale market (9). The WHO named this virus as COVID-19 on February 11, 2020, and declared it as a pandemic on March 11, 2020 (10).

Since the emergence of COVID-19, the number of publications on this novel coronavirus has grown rapidly and different aspects of this infection such as epidemiology, pathogenesis, transmission, prevention, treatment, complications, prognosis, etc, attract much interest. Also, many promising documents have been published to date, most of which having been accepted and released by prestigious journals like the Lancet, BMJ Clinical Research Ed, the Journal of Medical Virology, the Euro Surveillance: European Communicable Disease Bulletin, and JAMA. We also observed that most of the top cited articles have been published in these journals. In addition, about $84 \%$ of the documents in this field were open access, with the purpose of understanding this novel infection sooner and decreasing this serious health threat in humankind.

The country analysis based on the COVID-19 confirmed cases and the COVID-19 documents revealed that 7 out of top 10 countries with the most COVID-19 positive cases also worked the most in producing scientific documents and finding a solution for this pandemic. Spain, Iran, and Turkey which listed in the top countries with the most COVID-19 positive cases should pay more attention to this statistics in their policies.

The analysis of the most frequent keywords applying in the literature of COVID-19 revealed some hotspots of focus during the study period. For example, this novel virus has been used under different names in this area, including COVID-19, Coronavirus, 2019-nCoV, SARSCoV-2, and 2019 novel Coronavirus. In addition, during this time many studies have been conducted on the pathogenesis, epidemiology, transmission, and diagnosis of this virus; eg, (1) the similarity between this virus and other viruses from the Coronavirus family, such as SARS (severe acute respiratory syndrome) and MERS (Middle East respiratory syndrome); (2) the role of quarantine for the infection control of COVID-19 outbreak; (3) the diagnostic ability of CT scan (computed tomography);(4) ARDS (acute respiratory distress syndrome) complication; and (5) the status of this virus in the world as an epidemic which after a while changed into a pandemic. Interestingly, angiotensin-converting enzyme 2 (ACE2) is the only substrate in this network, suggesting its potential effect on the novel Coronavirus disease. ACE2 plays a critical role 
in the renin-angiotensin system (RAS) through which converts the angiotensin (Ang) I into Ang (1-9) and Ang II into Ang (1-7), respectively $(11,12)$, and accordingly contributes to cardiovascular diseases such as coronary artery disease, hypertension, congestive heart failure, and myocarditis (13). Many studies suggested that this enzyme could be a potential target in Influenza infection (H1N1, H7N9 and H5N1), inducing acute lung injury (14-16) and Coronavirus infection (SARS, HCoV-NL63 and 2019$\mathrm{nCoV}$ ) mainly through binding to the viral spike glycoprotein, which was a highly-focused subject in our bibliometric analysis on the most frequent terms in the literature of 2019-nCoV (17-20). Therefore, ACE2 could be targeted to manage COVID-19 disease in future studies.

However, some bibliometric studies on COVID-19 have been conducted so far (21-23) included fewer COVID-19 documents than ours due to earlier data extraction or the use of other databases. Therefore, this study provided the comprehensive perspective of the COVID-19 documents indexed in Scopus to date. Chahrour M et al (21) conducted a bibliometric analysis on 564 documents on COVID19 that had been published until March 18, 2020. They reported that China and the United States published most of these documents (377 and 39 documents, respectively) and Singapore ranked first based on the number of the documents per million persons $(\mathrm{n}=1.069)$.

Hossain MM (22) also conducted a bibliometric analysis on 422 COVID-19 documents indexed in Web of Science (WoS) core collection until April 1, 2020 and reported that China, the United States, the United Kingdom, Italy, and Canada produced the most documents on COVID-19 (185, 68, 36, 23 and 23 articles, respectively). In addition, top journals with the most COVID-19 documents were British Medical Journal $(\mathrm{n}=47)$, the Lancet (n $=37)$, Eurosurveillance $(\mathrm{n}=22)$, and Journal of Medical Virology $(\mathrm{n}=22)$. We found that their findings based on the searching in WOS database are consistent with the results of our analysis on the documents indexed in Scopus.

\section{Conclusion}

Since the emergence of COVID-19, many countries, journals, institutions, and researchers focused on this topic, which led to the rapid growing publications on this area of literature. To date, China, the United States, and the United Kingdom had the most scientific performance as well as international collaborations on COVID-19 research. The most published documents on COVID-19 were open access and were published in prestigious journals with high impact factors, including the Lancet, BMJ Clinical Research Ed, and Journal of Medical Virology. In addition, the present bibliometric analysis on COVID-19 literature shows the focused subjects in various aspects of this infection such as pathogenesis, epidemiology, transmission, diagnosis, treatment, prevention, and its complications.

\section{Conflict of Interests}

The authors declare that they have no competing interests.

\section{References}

1. Guan WJ, Ni ZY, Hu Y, Liang WH, Ou CQ, He JX, et al. Clinical characteristics of coronavirus disease 2019 in China. N Engl J Med. 2020;382:1708-1720.

2. Huang C, Wang Y, Li X, Ren L, Zhao J, Hu Y, et al. Clinical features of patients infected with 2019 novel coronavirus in Wuhan, China. Lancet. 2020;395(10223):497-506.

3. Zhou P, Yang XL, Wang XG, Hu B, Zhang L, Zhang W, et al. A pneumonia outbreak associated with a new coronavirus of probable bat origin. Nature. 2020;579(7798):270-273.

4. Wang W, Tang J, Wei F. Updated understanding of the outbreak of 2019 novel coronavirus (2019-nCoV) in Wuhan, China. J Med Virol. 2020;92(4):441-7.

5. Van Eck N, Waltman L. Software survey: VOSviewer, a computer program for bibliometric mapping. Scientometrics. 2009;84(2):52338.

6. Small H. Co-citation in the scientific literature: A new measure of the relationship between two documents. J Am Soc Inform Sci. 1973;24(4):265-9.

7.Zhu N, Zhang D, Wang W, Li X, Yang B, Song J, et al. A novel coronavirus from patients with pneumonia in China, 2019. N Engl J Med. 2020;382(8):727-733.

8. Li Q, Guan X, Wu P, Wang X, Zhou L, Tong Y, et al. Early transmission dynamics in Wuhan, China, of novel coronavirusinfected pneumonia. N Engl J Med. 2020;382(13):1199-1207.

9. Rothan HA, Byrareddy SN. The epidemiology and pathogenesis of coronavirus disease (COVID-19) outbreak. J Autoimmun. 2020;109:102433.

10. Cucinotta D, Vanelli M. WHO Declares COVID-19 a Pandemic. Acta Biomed. 2020;91(1):157-160.

11. Donoghue M, Hsieh F, Baronas E, Godbout K, Gosselin M, Stagliano N, et al. A novel angiotensin-converting enzyme-related carboxypeptidase (ACE2) converts angiotensin I to angiotensin 1-9. Circ Res. 2000;87(5):E1-9.

12. Tipnis SR, Hooper NM, Hyde R, Karran E, Christie G, Turner AJ. A human homolog of angiotensin-converting enzyme cloning and functional expression as a captopril-insensitive carboxypeptidase. J Biol Chem. 2000;275(43):33238-43.

13. Wu CH, Mohammadmoradi S, Chen JZ, Sawada H, Daugherty A, $\mathrm{Lu}$ HS. Renin-angiotensin system and cardiovascular functions. Arterioscler Thromb Vasc Biol. 2018;38(7):e108-e116.

14. Yang P, Gu H, Zhao Z, Wang W, Cao B, Lai C, et al. Angiotensinconverting enzyme 2 (ACE2) mediates influenza H7N9 virus-induced acute lung injury. Sci Rep. 2014;4:7027.

15. Zou Z, Yan Y, Shu Y, Gao R, Sun Y, Li X, et al. Angiotensinconverting enzyme 2 protects from lethal avian influenza A H5N1 infections. Nat Commun. 2014;5:3594.

16. Liu X, Yang N, Tang J, Liu S, Luo D, Duan Q, et al. Downregulation of angiotensin-converting enzyme 2 by the neuraminidase protein of influenza A (H1N1) virus. Virus Res. 2014; 185:64-71.

17. Li W, Moore MJ, Vasilieva N, Sui J, Wong SK, Berne MA, et al. Angiotensin-converting enzyme 2 is a functional receptor for the SARS coronavirus. Nature. 2003;426(6965):450-4.

18. Letko MC, Munster V. Functional assessment of cell entry and receptor usage for SARS-CoV-2 and other lineage B betacoronaviruses. Nat Microbiol. 2020;5(4):562-569.

19. Kuba K, Imai Y, Rao S, Gao H, Guo F, Guan B, et al. A crucial role of angiotensin converting enzyme 2 (ACE2) in SARS coronavirusinduced lung injury. Nat Med. 2005;11(8):875-9.

20. Wang C, Horby PW, Hayden FG, Gao GF. A novel coronavirus outbreak of global health concern. Lancet. 2020;395(10223):470-3.

21. Chahrour M, Assi S, Bejjani M, Nasrallah AA, Salhab H, Fares M, et al. A bibliometric analysis of Covid-19 research activity: A call for increased output. Cureus. 2020;12(3): E7357.

22. Hossain MM. Current status of global research on novel coronavirus disease (Covid-19): A bibliometric analysis and knowledge mapping. Available at SSRN 3547824. 2020.

23. Lou J, Tian SJ, Niu SM, Kang XQ, Lian HX, Zhang LX, et al. Coronavirus disease 2019: a bibliometric analysis and review. Eur Rev Med Pharmacol Sci. 2020;24(6):3411-21. 